\title{
A slightly more precise quantification of the effects of Microsoft's conduct
}

Citation for published version (APA):

Schinkel, M. P. (2002). A slightly more precise quantification of the effects of Microsoft's conduct. METEOR, Maastricht University School of Business and Economics. METEOR Research Memorandum No. 021 https://doi.org/10.26481/umamet.2002021

Document status and date:

Published: 01/01/2002

DOI:

10.26481/umamet.2002021

Document Version:

Publisher's PDF, also known as Version of record

\section{Please check the document version of this publication:}

- A submitted manuscript is the version of the article upon submission and before peer-review. There can be important differences between the submitted version and the official published version of record.

People interested in the research are advised to contact the author for the final version of the publication, or visit the DOI to the publisher's website.

- The final author version and the galley proof are versions of the publication after peer review.

- The final published version features the final layout of the paper including the volume, issue and page numbers.

Link to publication

\footnotetext{
General rights rights.

- You may freely distribute the URL identifying the publication in the public portal. please follow below link for the End User Agreement:

www.umlib.nl/taverne-license

Take down policy

If you believe that this document breaches copyright please contact us at:

repository@maastrichtuniversity.nl

providing details and we will investigate your claim.
}

Copyright and moral rights for the publications made accessible in the public portal are retained by the authors and/or other copyright owners and it is a condition of accessing publications that users recognise and abide by the legal requirements associated with these

- Users may download and print one copy of any publication from the public portal for the purpose of private study or research.

- You may not further distribute the material or use it for any profit-making activity or commercial gain

If the publication is distributed under the terms of Article $25 \mathrm{fa}$ of the Dutch Copyright Act, indicated by the "Taverne" license above, 


\title{
A Slightly More Precise Quantification of the Effects of Microsoft's Conduct
}

\author{
Maarten Pieter Schinkel*
}

May 2002

\begin{abstract}
This paper extends on the gripping analysis of possible consequences of the anticompetitive behavior of Microsoft Corporation in the market for computer operating systems offered in Hall and Hall (2000). It is concluded that the model of Hall and Hall offers much more reason to be suspicious of Microsoft's actions and intentions, as well as argument to further-reaching punishment than foreseen in the current remedy proposal, and than the authors themselves acknowledge.
\end{abstract}

\section{Introduction}

In a remarkable paper in this journal, Chris and Robert Hall propose a model of the market for personal computers (PC's) that come shipped with a pre-installed operating system (OS). ${ }^{1}$ The model offers an interesting understanding of the competitive process in this market, and particularly the perverse influence of Microsoft Corporation thereon. By means of slight-ofhand calibrations, it allows Hall and Hall to obtain a crude estimate of the social damages that derive from Microsoft's attempts to maintain a dominant position for its OS, Windows, by raising the costs necessary for potential competitors to produce a viable alternative - for example through Microsoft's

* Department of Economics, Universiteit Maastricht, P.O. box 616, 6200MD Maastricht, The Netherlands. E-mail: m.schinkel@algec.unimaas.nl.

1 Hall, C.E. and R.E. Hall, "Toward a Quantification of the Effects of Microsoft's Conduct," American Economic Review, May 2000, pp.188-91. 
secrecy around the hidden API's in Window's source code, its vaporware strategies and the company's legal threats. These costs are estimated at $\$ 6$ billion over the next five years.

Essentially, the model is a static limit-price model, where the sunk costs behind which Microsoft, as the incumbent firm, can hide and raise the price of Windows are the development costs of so-called 'self-supply' OS's for PC manufacturers. By raising these development costs through some of the strategies mentioned, Microsoft can correspondingly increase the limit price of Windows, and thus its profits.

Hall and Hall argue quite convincingly that the type of model they propose is a plausible description of actual competition in the PC market, by observing - as others have in U.S. vs. Microsoft Corp.- that the sales price for Windows, some $\$ 60$, is far less than the price Microsoft could have asked for its OS, if it indeed had a monopoly and faced no threat of entry. In their calibrated version of the model, Hall and Hall estimate this true monopoly price to be equal to $\$ 813 .^{2}$ The argument presses their model as quite fitting indeed, as it leads to the conclusion that the barrier to entry that forces the price of Windows OS down to $\$ 60$ is in the order of $\$ 9$ billion for developing a viable alternative OS to Windows from scratch. ${ }^{3}$ Hall and Hall celebrate this effect as a

"...great victory for virtual competition: not only is the price

2 There is a slight ommission in the derivation of this price, that leads to an underestimation of the potential competition effect even. The monopoly price would maximize Microsoft's profits, given the relationship between the price for Windows and that of PC's set by the manufacturers. That is, Microsoft would maximize

$$
r Q=\left(\left(\frac{\epsilon M-1}{\epsilon M}\right) p-c\right)\left(\frac{p}{\alpha}\right)^{-\epsilon} .
$$

Hence, the monopoly price for PC's would be

$$
\left(\frac{\epsilon M}{\epsilon M-1}\right)\left(\frac{\epsilon}{\epsilon-1}\right) c=\$ 1875
$$

and that of Windows $\$ 895$ (that is, the marginal costs of producing a computer), instead of the $\$ 813$ that follows from equation (4) on page 189 .

3 Again, the presented version of the model is slightly peculiar, as it is stated that one of the $M$ PC producers considers 'self-supplying' an OS, yet calculations are carried out with $M+1$ producers henceforth. Correction for this leads to barrier of entry of about $\$ 11$ billion at a price for Windows of $\$ 60$, which is substantial. In the following, we will remain to the original specification in Hall and Hall (2000). 
of Windows brought down to a small fraction of its monopoly price, but the social waste of duplicative investment in operating systems is avoided as well." (op.cit., p.189, right column)

And rightly so. However, it is not the merit of Microsoft that it materializes. Quite the contrary. It has been Microsoft's objective to raise the investments necessary for potential competitors to produce alternatives to Windows OS, by all sorts of means - and for this it was indeed convicted. Therefore, it is very well possible that the $\$ 9$ billion are mostly of Microsoft's making. The true cost may well be far lower. Just to get the idea, in the extreme case in which the copyright protection of Windows OS were fully lifted, the costs would drop to nil, i.e., the cost of making a copy of Windows.

The truly interesting question to pose to the model of Hall and Hall, therefore, concerns the order of magnitude of the welfare effects of Microsoft raising the barrier of entry to the OS market. Hall and Hall (2000) provides all the tools necessary for this, yet does not quite perform the analysis to this effect. In fact, Hall and Hall consider somewhat of the opposite: a lowering through antitrust measures of the developments costs from $\$ 9$ billion to $\$ 7$ billion. And for this case, they offer the very crude welfare measure of the costs of a higher price of Windows (and consequently PC's) for computer purchasers, the $\$ 6$ billion mentioned above - a number they, moreover, take seriously enough to argue that any penalty for Microsoft's wrongdoing should not exceed it. ${ }^{4}$ Naturally, it would be more appropriate to consider the deadweight welfare loss that Microsoft creates with its behavior in the PC market. Particularly since the Hall and Hall model offers such a gripping setup for this, we extend their analysis in this direction, in an attempt to obtain a slightly more precise quantification of the effects of Microsoft's conduct.

\section{An Analysis of Dead-Weight Loss}

The level of development costs of a 'self-supply' OS that Hall and Hall find explains the present price of Windows OS of $\$ 60$ is, as said, $\$ 9$ billion. If indeed this level is higher than strictly necessary due to Microsoft's strategic behavior, the social costs of this anticompetitive behavior depend on the level of development costs necessary without Microsoft's inflationary conduct. Naturally, estimates of such would-be costs are hard to come by. Insight into

4 Op.cit., p.190 right column. 
the damage potentially done can be obtained, however, by considering the percentage by which Microsoft possibly raised the costs of producing a viable alternative to Windows over the true production costs, $D_{\text {true }}$, thereof. Let this percentage be $d$, thus defined as

$$
d=\frac{9 \times 10^{9}-D_{\text {true }}}{D_{\text {true }}} .
$$

The Harberger triangle under the estimated demand for PC's in the Hall and Hall model is then quite readily derived for different values of $d$. The equilibrium price for PC's that derives from the level of costs for a self-supplied $\mathrm{OS}$ is defined by their equation (7). For any level of $d$, the corresponding price for a $\mathrm{PC}, p_{d}$, therefore is implicit in

$$
\epsilon\left(\frac{\left(p_{d}-c\right)^{2}}{p_{d}}\right)\left(\frac{p_{d}}{\alpha}\right)^{-\epsilon}-K=\frac{9 \times 10^{9}}{d+1},
$$

where $\epsilon=2$ is the elasticity of demand, $c=895$ are the marginal costs of producing a computer, $\alpha=24.496$ million is a demand parameter, and $K=2.5$ billion are the fixed productions costs of a PC manufacturer. ${ }^{5}$

Given that inverse demand is

$$
p=\alpha Q^{-\frac{1}{\epsilon}}
$$

dead-weight losses corresponding to levels of $d \geq 0$ are found as

$$
D W L=\int_{Q_{d}}^{Q_{0}} \alpha Q^{-\frac{1}{\epsilon}} d Q-\alpha\left(Q_{0}-Q_{d}\right) Q_{0}^{-\frac{1}{\epsilon}} .
$$

The effect of lowering development costs from $\$ 9$ to $\$ 7$ billion through antitrust intervention, as considered by Hall and Hall, then is already substantial: to $d=\frac{2}{7}$ corresponds a rise in computer prices from $\$ 981.5$ to $\$ 991.7$, a corresponding drop in sales from 622.9 to 610.1 million, resulting in a dead-weight loss of $\$ 126.3$ million. For several non-specific values of $d$, running from zero up to Microsoft quadrupling the true costs of developing an alternative to Windows OS, the table below displays the damages.

5 The somewhat specific value of $\alpha$ is not explicit in Hall and Hall (2000), but follows by close approximation from some of the numbers they report. The analysis turns out to be very sensitive to the value of $\alpha$, which originally may have been 25 million. 


\begin{tabular}{|l|l|l|l|}
\hline$d$ & $p_{d}($ in $\$)$ & $Q_{d}$ (in millions) & $D W L$ (in millions of $\$$ ) \\
\hline 0 & 991.7 & 610.1 & 0 \\
\hline$\frac{1}{4}$ & 982.6 & 621.5 & 57.2 \\
\hline$\frac{1}{2}$ & 976.2 & 629.7 & 98.0 \\
\hline$\frac{3}{4}$ & 971.4 & 635.9 & 128.7 \\
\hline 1 & 967.7 & 640.8 & 152.9 \\
\hline $1 \frac{1}{2}$ & 962.3 & 648.0 & 188.2 \\
\hline $1 \frac{3}{4}$ & 960.3 & 650.7 & 201.4 \\
\hline 2 & 958.5 & 653.1 & 213.1 \\
\hline $2 \frac{1}{2}$ & 955.7 & 657.0 & 232.0 \\
\hline 3 & 953.6 & 659.9 & 246.1 \\
\hline
\end{tabular}

Table 1: Possible damages from Microsoft raising the barrier of entry into the OS market from $\$ 2.25$ billion to the present $\$ 9$ billion.

Clearly, the social costs associated with Microsoft's anti-competitive behavior are, even when the company indeed succeeded in quadrupling the development costs of an alternative to Windows from $\$ 2.25$ billion to the $\$ 9$ billion, only small relative to total sales - and total welfare in this market, for that matter. ${ }^{6}$ Still, and for Harberger triangle standards, they are substantial and cause for concern.

\section{A Note on Possible Penalties}

Hall and Hall put as a cap on possible penalties for Microsoft the gain in returns to the company of raising the price of Windows through increasing the barrier to entry from $\$ 7$ to $\$ 9$ billion-which they find is $\$ 6$ billion, see below. They argue that:

"If the creation of those artificial barriers was Microsoft's only wrongdoing, then the damages owed to past purchasers of computers should be based on a similar dollar amount. More aggressive punishment of Microsoft (such as breaking it up into competing entities) that lower shareholder value by more than $\$ 6$ billion, may fail the standard of fitting the punishment to the crime." (op.cit., p.190, right column)

\footnotetext{
6 Note that these estimates are quite conservative, with regards to note 3.
} 
Again, this conclusion is a little quick, and in need of correction-particularly now that the weakening of US. vs. Microsoft Corp. by the Court of Appeals' February 2001 partial dismissal of the complaint of monopolization of the browser market through the predatory distribution of Internet Explorer, helped by ill-timed public appearances of Judge Thomas Penfield Jackson and a shift in political power in the US, have created an atmosphere in which a settlement proposal that basically allows Microsoft to get away with just the promise to better its life is about to be taken over by the court.

In order to prevent felonies of this kind - and a felony it is, according to the Sherman Act - any penalties are to balance the expected benefits of breaking the law. If not, other companies in similar circumstance may well conclude that the antitrust authority shoots with feather. What would be an appropriate penalty is, of course, quite difficult to determine. The ex ante probability that the intended anticompetitive strategy will be a success plays a role, just as that of being caught in the act. Also, anticompetitive behavior can be costly, and the benefits when they are a success not easy to determine up front.

Yet, to get an impression of the extra profits Microsoft might have had its eye on, the model of Hall and Hall offers a handle again. Quite straightforwardly, it allows for identifying the increased returns to Microsoft Corporation for any level of $d$, as follows. The price of Windows, $r_{d}$, derives from that of PC's, $p_{d}$, by equation (8). It reads

$$
r_{d}=\left[\frac{\epsilon(M+1)-1}{\epsilon M}\right] p_{d}-\left(\frac{M+1}{M}\right) c,
$$

in which $M=11$ is the number of (identical) PC manufacturers. Consequently, the following table, in which $\Delta R_{d}$ is the extra return from raising the barrier by the factor $d$, is readily filled. ${ }^{7}$

Clearly, Microsoft's potential gains have been substantial. That alone gives sufficient reason for levying a hefty fine. Yet, the model offers clues for more concern still - concern that was, in fact, behind the original break-up proposal. Microsoft's strategy has been costly to the company at the time it was chosen in at least two ways - that is, apart from the antitrust measures it now faces. Firstly, to increase the development costs of potential

\footnotetext{
$7 \quad$ Hall and Hall's case, leading to the increase of $p_{d}$ from $\$ 981.5$ to $\$ 991.7$, results in an increase in $r_{d}$ from $\$ 49.8$ to $\$ 60.4$, and consequently to the increased benefit to Microsoft of $\$ 6$ billion ( $\$ 5.8$ billion).
} 


\begin{tabular}{|l|l|l|l|}
\hline$d$ & $r_{d}($ in $\$)$ & $Q_{d}$ (in millions) & $\Delta R_{d}$ (in billions of $\left.\$\right)$ \\
\hline 0 & 60.4 & 610.1 & 0 \\
\hline$\frac{1}{4}$ & 50.9 & 621.5 & 5.2 \\
\hline$\frac{1}{2}$ & 44.2 & 629.7 & 9.0 \\
\hline$\frac{3}{4}$ & 39.2 & 635.9 & 11.9 \\
\hline 1 & 35.3 & 640.8 & 14.2 \\
\hline $1 \frac{1}{2}$ & 29.7 & 648.0 & 17.6 \\
\hline $1 \frac{3}{4}$ & 27.6 & 650.7 & 18.9 \\
\hline 2 & 25.7 & 653.1 & 20.1 \\
\hline $2 \frac{1}{2}$ & 22.8 & 657.0 & 21.9 \\
\hline 3 & 20.6 & 659.9 & 23.3 \\
\hline
\end{tabular}

Table 2: Extra returns to Microsoft from raising the barrier of entry into the OS market from $\$ 2.25$ billion to the present $\$ 9$ billion.

rivals requires direct expenses in advertizement and legal campaigns, and, for example, the giving away of Internet Explorer. Secondly, and more importantly, however, Microsoft forewent profits by setting a limit price in an attempt to maintain its dominant position.

Suppose that the first type of costs are negligeable - typically, they are not, but that only fortifies our conclusions. Then consider the critical level of the indirect costs below which Microsoft would no longer opt for a limit price strategy. This can be established as follows. The indirect costs of the limit price strategy are the sacrifice of the alternative behavior, which in the present model is sharing the market with a 'self-supplier'. The return of Microsoft to that alternative strategy would have been given as

$$
\begin{aligned}
R_{a c c} & =r\left(1-\epsilon \frac{(p-c)}{p}\right) Q=r\left(1-\epsilon \frac{(p-c)}{p}\right)\left(\frac{p}{\alpha}\right)^{-\epsilon} \\
& =r \frac{M c+(1-\epsilon) M r}{(M+1) c+M r}\left(\frac{\epsilon(M+1) c+\epsilon M r}{(\epsilon(M+1)-1) \alpha}\right)^{-\epsilon},
\end{aligned}
$$

where $\left(1-\epsilon \frac{(p-c)}{p}\right)$ is Microsoft's share in OS market in the asymmetric Cournot equilibrium that establishes - $c f$. Hall and Hall's equation (6)and the price of Windows $r$ is expressed in that of PC's $p$ using equilibrium characterization (5) in Hall and Hall. In general, the returns of the limit 
price strategy are

$$
R_{\lim i t}=\left(\frac{\epsilon(M+1)-1}{\epsilon M} p-\frac{M+1}{M} c\right)\left(\frac{p}{\alpha}\right)^{-\epsilon} .
$$

Interestingly enough, the level of $D$ that just equates $R_{a c c}$ and $R_{\lim i t}$ is around $\$ 17.8$ billion. Below that level, an accommodation strategy would have delivered a higher profit than one of entry deterrence. Or, to put it differently, given Hall and Hall's specifications, accommodation leads to a profit maximizing price of Windows of $\$ 250$, a corresponding price of $\$ 1173.3$ per $\mathrm{PC}$ and, therefore, materializes as $R_{a c c}=\$ 57.4$ billion. So, even if Microsoft was able to quadruple the level of development costs - at no direct costs, mind you - it would have raised its profits more than two times over its chosen strategy of entry deterrence by accommodating entry into the OS market. Hence, Microsoft's revealed strategy of limit pricing at $\$ 60$, behind a possibly self-raised barrier of $\$ 9$ billion - and provided one accepts the Hall and Hall model as plausibile - indicates that the company expected to benefit from its anticompetitive behavior in the OS market in other ways, and more, than just the extra profits in the existing market. If instantaneous profits would have been the objective, the company would either have raised the barrier further-possibly it was kept from doing so out of fear for antitrust investigation - or it would have opted for a strategy of accommodation. Keeping entrants out has obvious long term benefits, such as hinderance of technical advance of viable alternatives to Windows, dominance in the access to subscription software - predicted as the future of software - or a lock-in of programming languages to Microsoft's advantage. There is ample reason to think these considerations played a role in Microsoft's conduct. They should weigh in remedy deliberations. 